\title{
Exploring the Effectiveness of Critical Thinking on Vocabulary Learning by Malaysian EFL Learners
}

\author{
Maryam Sharafi-Nejad (Corresponding author) \\ School of Educational Studies \\ Universiti Sains Malaysia, 11800, Penang, Malaysia \\ E-mail:msn12_edu085@student.usm.my
}

Shohreh Raftari

Faculty Member of Medicine Department

University of Medical Sciences, Kerman, Iran

E-mail: Raftari2004@yahoo.com

Shaik Abdul Malik Mohamed Ismail

School of Educational Studies

Universiti Sains Malaysia, 11800, Penang, Malaysia

E-mail: samalik@usm.my

\author{
Lin Siew Eng \\ School of Educational Studies \\ Universiti Sains Malaysia, 11800, Penang, Malaysia \\ E-mail: selin@usm.my
}

Received: Feb. 3, 2016 Accepted: May 29, 2016 Published: May 29, 2016

doi:10.5296/jse.v6i2.9520 URL: http://dx.doi.org/10.5296/jse.v6i2.9520 


\section{Abstract}

Based on the findings of previous studies which highlight the role of vocabulary knowledge in English as a Foreign Language/English as a Second Language (EFL/ESL) learners' learning process, this study is aimed at exploring the effectiveness of critical thinking on vocabulary learning by Malaysian EFL learners. .To achieve the purpose of this study, 60 male undergraduate EFL learners studying English at Asian EFL Academy Language Institute in Pinang were selected after administering Preliminary English Test. To examine whether there is a significant difference between experimental and control group, two parallel versions of Vocabulary Knowledge Scale (Pribakht \& Wesche, 1993) were used as pre-test and post-test. The participants in experimental group were instructed on how to employ critical thinking strategies on vocabulary learning. The results of the post-test showed that the experimental group who received formal instruction based on the critical thinking strategies revealed the prominent development and interest in vocabulary learning. The t-test also indicated a significant difference between the performance of the control and experimental group.

Keywords: Critical thinking ability, vocabulary learning strategies, EFL learners, Lexical knowledge. 


\section{Introduction}

It is important that language learners and teachers should use lexicon precisely and critically. The lexicon is known as vocabulary, which is one of the most important components of language. It is the fact that without it, individuals cannot convey their ideas to others (Allen, 1983). Previous researchers (e.g., Knight, 1994; Wesche \& Paribakht, 1996; Zimmerman, 1997) also highlighted a significant role of vocabulary in L2 acquisition. Therefore, it is necessary to propose a novel but effective approach for learning and teaching vocabulary.

Consistent with the notion that learning the first language is largely dependent on the knowledge of vocabulary(Thornbury, 2002), there is now a unanimous consensus among English as a Foreign Language (EFL) educators that the quality and quantity of EFL learners learning language are determined, to a large extent, with learners' vocabulary knowledge (Decarrico, 2001; Hatch \& Brown, 1995; Maley,1986; Schmitt,2000). That is why many EFL educators argue that inadequacy of lexical knowledge may hamper or slow down language learning (Fan, 2003). However, for many EFL learners, vocabulary learning is an extremely challenging task (Catalan, 2003; Hiebert, 2011; Read, 2000).

To date, a wide range of approaches, techniques, exercises and practices has been used for vocabulary teaching as it is challenging for L2 learners to learn vocabulary. For this reason, it is suggested by Hulstijn (1993) that teachers should teach their students strategies that are potential to the improvement in the knowledge of vocabulary in addition to teaching specific words. It is the truth that most learners are less interested in learning vocabulary when they are required to spend a great deal of time memorizing and learning a word (Allen, 1983). That is why it will be more efficient if the teachers attempt to teach their students unfamiliar words within a limited time through more effective approaches or techniques.

In recent years, a number of researchers (e.g., Dornyei, 2005; Ehrman, Leaver, \& Oxford, 2003; Norton, 2001; Robinson, 2002) have paid attention to research on learner traits and critical thinking ability. There is a shift from behavior-oriented theories of learning to cognition-oriented one due to learners' need for their jobs (Ustunuoglu, 2004). This shift focuses on the important role of the performance of learners compared to the teachers. The cognitive approaches are highly appreciated in language teaching, which indicates the relationship between thinking and language. Thus, it was shown that thinking skills are enhanced when knowledge-production behavior of learners are monitored more carefully than their knowledge-reproduction performance. This is because critical, creative, and scientific thinking is emphasized in the process of knowledge-production.

Critical Thinking (CT) is one of the significant internal factors which is believed to have a major influence on the process of learning and the way EFL learners deal with input and produce output (Chamot, 1995; Nosratinia \& Zaker, 2013).CT, as a high level of cognitive function, "is a purposeful, self-regulatory judgement which results in interpretation, analysis evaluation, and inference, as well as explanations of evidential, conceptual, methodological or contextual considerations upon which the judgement is based" (Astleitner,2002, p.53). Such a cognitive factor, according to Wagner (1997), would enable individuals to develop expertise in many areas of life. 


\section{Review of the Related Literature}

There are numerous ways to define critical thinking. However, this concept has not been defined in a consistent way. According to Kadir (2007), this problem is caused by a relation between critical thinking and various perspectives of philosophy and psychology. For example, the notion of critical thinking is emphasized by philosophers, whereas the notion of critical thinking skills is highlighted by psychologists. Additionally, critical thinking is characterized by Noddlings (2006) as a way to explain the decision making, conduct, and belief of individuals precisely and logically. Meanwhile, Cottrell (2005) defined that critical thinking refers to a cognitive activity which is not separated with the use of the mind.

There is a close relationship between critical thinking and learning. Indeed, this view is confirmed by Paul and Elder (2005) that critical thinking is related to learning due to a key insight. It is also stated that thinking of people is just improved when people are in the process of learning. It means that there is a positive outcome of learning when people have their good thinking. By contrast, poor learning results in poor thinking. Therefore, it can be concluded that learning plays a key role in improving critical thinking of human because it acts as a means of connection and collaboration. It was also highlighted that careful reading and listening are two main activities required for the enhancement of critical thinking. Likewise, Duron, Limbach, and Waugh (2006) indicate the benefits of active learning that students' critical thinking is enhanced due to the more pleasant atmosphere for both teachers and students (p.160). However, it receives some criticisms from scholars. In fact, a pleasant feeling of people is hindered because the interactions among individuals are well monitored.

Mok (2010) indicate two main aspects of critical thinking. The first aspect refers to a learning space, whereas the second one mentions classroom teaching. The first aspect suggests that learning should be organized in an active way to motivate students' engagement in their learning process. It was, moreover, suggested that students should be provided with the process of critical thinking to distinguish the critical features of various critical attitudes. Meanwhile, it is suggested in the second aspect that the process of meaningful critical thinking occurs when teachers raise effective questions to involve their students' engagement in authentic discussions.

Our life needs critical thinking as it is considered as one of the important skills required for human (Mimbs, 2005; Halvorsen, 2005). Therefore, it is necessary that key elements of critical thinking should be applied into the classrooms. This view is also supported by Davidson (1998); Waters (2006); and Liaw (2007). Moreover, Paul and Elder (2005) proposed four reasons (i.e., accelerating change, intensifying complexity, escalating interdependence, and increasing danger) why critical thinking becomes more important (p.12).

The relationship between critical thinking and various areas of language has been explored by a number of researchers. For example, Mirzai (2008) investigated the relationship between critical thinking and lexical inferencing of Iranian EFL learners. To conduct this research, participants include 130 male and female students who were selected from an institute of language. For data collection, a questionnaire of TOEFL and Honey critical thinking including 30 items were delivered to these students. From the obtained results, those students who have 
higher critical thinking ability outperform better than those who have lower critical one in lexical inferencing.

Kamali and Fahim (2011) conducted a study to examine whether there is any relationship between critical thinking ability, resilience, and reading texts with unfamiliar vocabulary items. In this study, Appraisal test of Honey (2004), Resilience Scale of Connor and Davidson (2003), a checklist of vocabulary, and a validated battery of four reading comprehension tests were administered to 63 intermediate EFL learners. Three findings were found: (1) critical thinking level significantly affects participants' scores on the resilience scale, (2) critical thinking level significantly affects the participants' comprehension of reading texts with unfamiliar vocabulary items, and (3) resilience level significantly affects the participants' comprehension of reading texts with unfamiliar vocabulary items.

The effects of students' learning style on critical thinking skill were investigated by Myers and Dyer (2006). In this research, participants include 135 students who were attending the courses of agriculture and life sciences leadership in Florida University. The Gregorc Style Delineator was administered to evaluate each student's the preferred learning style. The test of Cornell Critical Thinking was also administered to determine each student's the critical thinking skills. The results revealed no difference in critical thinking skills between male and female students. However, it was shown that students who deeply embedded abstract sequential learning style preferences had higher scores on critical thinking than others. No difference in critical thinking ability between students of other learning styles was also found.

Brookfield (2010) indicated three main aims of developing critical thinkers: (1) helping readers to know about critical thinking phenomenon, describing its key components, providing examples to explain how to observe it at the actions of people, and providing the research and conceptual base for this activity; (2) examining different methods, techniques as well as approaches used for seeking for persons who help enhance critical thinking skills; (3) exploring the chances for individuals to be critical thinkers in four specific arenas, all of which are important to the life of most adults in their relationship, at their workplace, and potential to political involvements regarding the mass media which affects their perceptions of the world. The intended readers are all those professionals, managers, and educators who desire to understand, and develop critical thinking skills of their colleagues, clients, learners, and peers.

A study on the evaluation of the predictive power of Iranian English language learners' critical thinking on their performance on inferential reading comprehension tests was conducted by Boloori (2010). The results showed a significant correlation between critical thinking and inferential reading comprehension.

\section{Research Questions}

To fulfil the aims of the present study, the following specific question guide the collection and analysis of data:

1. Is there any relationship between the use of critical thinking strategies and EFL learners' vocabulary learning ability? 


\section{Method}

This research aims to explore the effectiveness of critical thinking on vocabulary learning by Malaysian EFL learners. To do this end, the present study was accomplished, and the following method and design were applied.

\subsection{Participants}

The sample of this study was 60 male undergraduate EFL learners, selected from 110 enthusiastic EFL students, who were studying English at Asian EFL Academy Language Institute in Pinang, Malaysia. The participants in the 19-25 age range were selected based on their performance on the Proficiency (PET) test. The main medium of instruction in this context was English; however, learners' first language (L1; Malay) was used. This research was a classroom experiment. In this study, it is impossible to select the students randomly. Therefore, an intact group design was employed in this research. According to Mackey and Gass (2005), the groups were intact in design; they were semi-randomly assigned to control and experimental groups.

\subsection{Materials and Instrument}

Two instruments were used for data collection: (1) 504 Absolutely Essential Words (5 ${ }^{\text {th }}$ ed.) was used as a course book, and (2)Vocabulary Knowledge Scale (VKS) proposed by Paribakht and Wesche (1993)was used as a pre-test and post-test. Tests of depth of lexical knowledge are grouped into two categories: (1) tests for analyzing different aspects of lexical knowledge, and (2) 'developmental' tests for identifying knowledge level considered as stages of acquiring the word (Read, 1997, p. 315).Designing accurate tests for the assessment of the complicated multidimensional construct of lexical knowledge is difficult, so the existing tests are grouped into category (b) using some sort of rating scale, in this case, VKS.

Table3.1. The VKS scoring categories: Assignment of Scores to Responses

\begin{tabular}{lll}
\hline $\begin{array}{l}\text { Self-report } \\
\text { Categories }\end{array}$ & $\begin{array}{l}\text { Possible } \\
\text { Scores }\end{array}$ & \multicolumn{1}{c}{ Meaning of Scores } \\
\hline I & 1 & The word is not familiar at all \\
\hline II & 2 & The word is familiar but its meaning is not known \\
\hline III & 3 & A correct synonym or translation is given \\
\hline IV & 4 & The word is used with semantic appropriateness in a sentence \\
\hline V & 5 & $\begin{array}{l}\text { The word is used with semantic appropriate and grammatical accuracy in a } \\
\text { sentence. }\end{array}$ \\
\hline
\end{tabular}

Its five-point scale measures learners' receptive (categories III \& IV) and productive (category V) knowledge about a specific word, which can verify actual knowledge against perceived knowledge. This instrument uses a five-point scale combining self-report and performance items to elicit self-perceived and demonstrated knowledge of specific words in written form. The scale ratings range from total unfamiliarity, through recognition of the word and some idea of its meaning to the ability to use the word with grammatical and semantic accuracy in a sentence. For example, an unsuccessful attempt at Level V or IV will 
result in a score of 2, 3 or 4 . If knowledge of a meaning of the word is shown in a Level $\mathrm{V}$ response, but the word is appropriately used in the sentence context, a score of 3 is given- And so on.

Finally, the assessment purpose of this research seems to fit quite nicely with the VKS's proclaimed purpose to "track the early development of specific words in an instructional or experimental situation" (Wesche \&Paribakht, 1996, as cited by Read, 2000, p. 33). In this research the parallel form of the pre-test was used in the post-test, and then the test score reliability is assessed through the correlation coefficient between the scores obtained from the two forms.

\subsection{Design}

The design of the study was quasi-experimental design. Convenience sampling was used in this research because it is often impossible for researchers to assign students randomly to language classes (Hatch \& Farhady, 1981; Mackey \& Gass, 2005). Therefore, in this study, the groups were semi-randomly assigned as the control group and the experimental group. In this study critical thinking strategies are considered as independent variables and vocabulary learning is considered as dependent variable.

\subsection{Procedure}

In order to achieve the purpose of the study, the following procedures were pursued:

After obtaining a formal approval for conducting the research in the context of the study, two classes were randomly selected from the available classes taking 504 absolutely essential words course at Asian EFL Academy Language Institute in Pinang. Initially, to homogenize the participants ,students were placed in classes on the basis of PET as a placement test in Asian EFL Academy Language Institute, this test was established the initial differences or similarities of two groups.

The researcher held 15 sessions of teaching and practicing critical thinking techniques classes during 5weeks and each session 90 minutes. They administered two tests of pre-test and post-test in order to test the research question and investigate the impact of critical thinking strategies on EFL learners vocabulary knowledge . According to VKS developed by Paribakht and Wesche (1993), these two tests are used to trace any significant differences between the two groups' performance. The experimental group was instructed on how to engage the participants in the process of thinking, make the participants familiar with the critical thinking techniques through reading as much as possible and tried to extend the techniques in all levels using their background knowledge experience, connecting different information, making inferences, annotating, and generally being critical.

The activities used in experimental group share two basic characteristics: First, they all concentrate on various aspects of vocabulary awareness and secondly they encourage the use of dictionary work in the classroom, it is crucial that EFL teachers train their learners in the use of both monolingual and bilingual dictionaries. It is equally crucial that teachers emphasize the importance of using dictionaries for specified purposes (Moore, 2005 as cited in Palmberg, 
2006). All of the participants took part in pre-test then after the explicit instruction period, a post-test of VKS was given. Post-test aims to determine to what extent the participants were familiar with the critical thinking strategies after almost 5 weeks. To examine whether teaching critical teaching strategies enhances the understanding of critical thinking techniques for participants, the researcher compared the results with their answers at the beginning of the first session.

\section{Results and Discussion}

To examine if the proficiency level of participants in both groups was the same at the beginning of the study, an independent samples t-test was used. As shown in Table 5.1, there is no statistically significant difference in the mean scores on the pre-test of both groups $\left(\mathrm{M}_{\mathrm{EG}}\right.$ : 18.00, $\left.\mathrm{SD}_{\mathrm{EG}}: 8.175 \& \mathrm{M}_{\mathrm{CG}}: 17.40, \mathrm{SD}_{\mathrm{CG}}: 8.127\right)$. It can be concluded that vocabulary knowledge of students in both groups was the same at the beginning of the study.

Table 5.1. Results for experimental and control groups

\begin{tabular}{|lc|c|c|c|c|}
\hline \multicolumn{2}{|c|}{ Study groups } & $\mathrm{N}$ & Mean & St. Deviation & $\begin{array}{c}\text { Std. Error } \\
\text { Mean }\end{array}$ \\
\hline Pre-test Scores & Experimental group & 30 & 18.00 & 8.175 & 1.493 \\
& Control group & 30 & 17.40 & 8.127 & 1.484 \\
\hline Post-test Scores & Experimental group & 30 & 34.33 & 12.344 & 2.254 \\
& & & & & 1.437 \\
\hline
\end{tabular}

Table 5.2. Independent sample test based on pre-test and post-test scores of study groups

\section{Independent Samples Test}

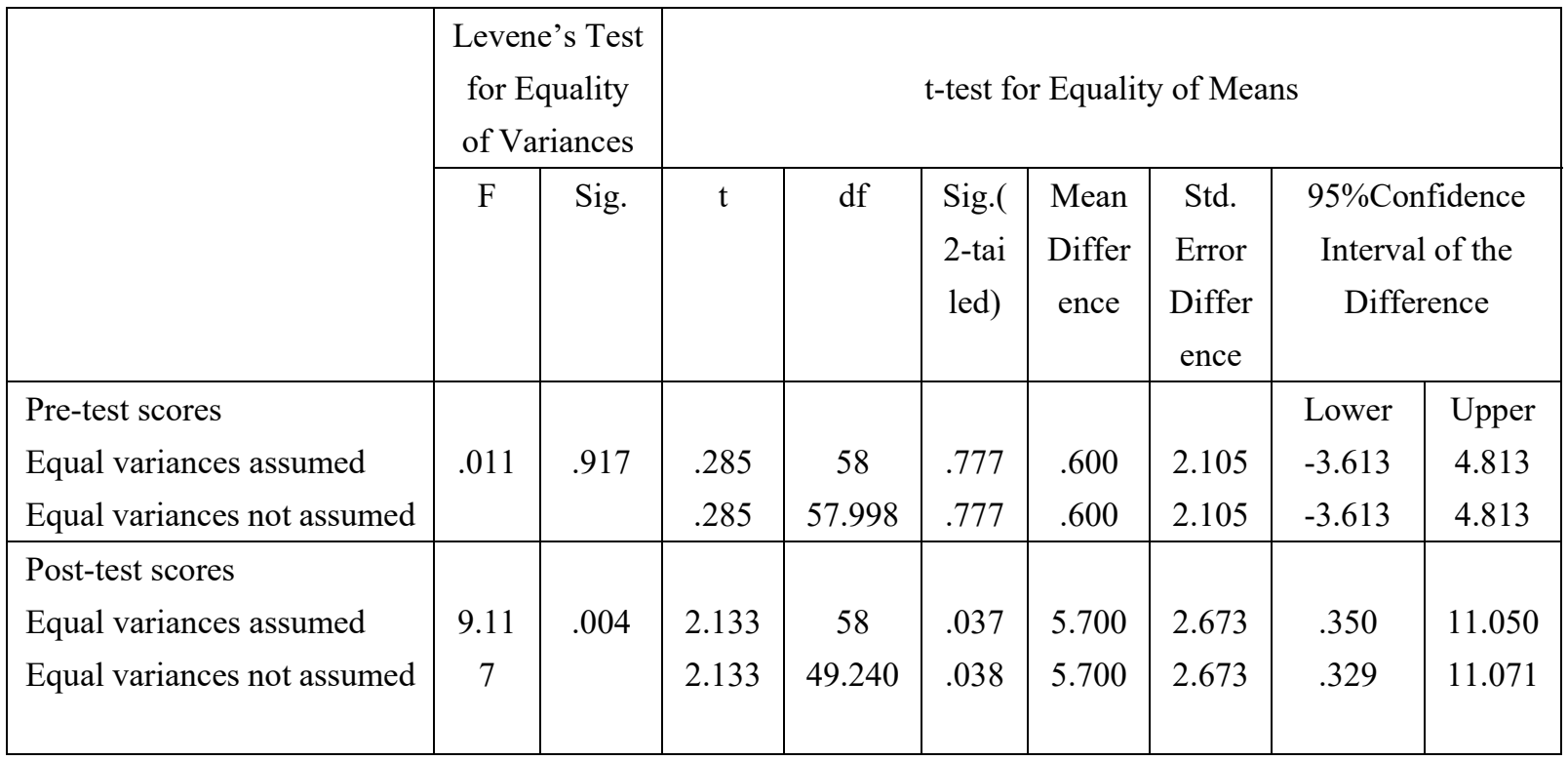




\section{Al Macrothink}

Based on the results of pre-test scores there was not a statistically significant difference between the control and experimental groups $\left(\mathrm{t}_{\text {pre-test }}(58)=0.28 ; \mathrm{p}>0.05\right)$. On the other hand, the results showed that there was a statistically significant difference between control and experimental groups with respect to their post-test scores $\left(t_{\text {post-test }}(58)=2.13 ; \mathrm{p}<0.05\right)$.

According to the results, it shows that the mean scores of the control and experimental groups were different in the post-test; it means that the mean score of the experimental group was more than the control group in the post-test. Meanwhile, the mean scores of the control and experimental groups were very close to each other in the pre-test.

Table 5.3. Paired Sample Statistics between two pairs

Paired Samples Statistics

\begin{tabular}{|ll|l|l|l|l|}
\hline & & Mean & N & Std. Deviation & Std. Error Mean \\
\hline Pair1 & Exp. group pre test scores & 18.00 & 30 & 8.175 & 1.493 \\
& & & & & \\
\multirow{2}{*}{ Pair2 } & Exp. group post test scores & 34.33 & 30 & 12.344 & 2.254 \\
& & 17.40 & 30 & 8.127 & 1.484 \\
& Con. group pre test scores & & & & 1.437 \\
\hline
\end{tabular}

According to assess whether there were any significant differences between the pre-test and post-test scores of each of the groups ,the paired samples t-test was used .Based on the results the difference between the means was statistically significant for control and experimental groups, as a consequence their performances were different in the pre-test and post-test $(\mathrm{t}$ experimantal $\left.(29)=-5.58 ; p<0.05 \& t_{\text {control }}(29)=-5.24 ; p<0.05\right)$.

Table5.4. Correlations between paired samples

\section{Paired Samples Correlations}

\begin{tabular}{|c|c|c|c|c|}
\hline & & $\mathrm{N}$ & Correlation & Sig. \\
\hline \multirow{2}{*}{ Pair1 } & Exp. group pre test scores & \multirow{3}{*}{30} & \multirow{3}{*}{-.186} & \multirow{3}{*}{.326} \\
\hline & $\&$ & & & \\
\hline & Exp. group post test scores & & & \\
\hline Pair2 & Con. group pre test scores & \multirow{3}{*}{30} & \multirow{3}{*}{-.077} & \multirow{3}{*}{.684} \\
\hline & $\&$ & & & \\
\hline & Con. group post test scores & & & \\
\hline
\end{tabular}


Table 5.5. T-test in paired samples

Paired Samples test

\begin{tabular}{|c|c|c|c|c|c|c|c|c|}
\hline & \multicolumn{5}{|c|}{ Paired Differences } & \multirow[t]{3}{*}{$\mathrm{t}$} & \multirow[t]{3}{*}{$\mathrm{df}$} & \multirow{3}{*}{$\begin{array}{l}\text { Sig }(2- \\
\text { tailed } \\
\quad)\end{array}$} \\
\hline & \multirow[t]{2}{*}{ Mean } & \multirow[t]{2}{*}{$\begin{array}{l}\text { Std.De } \\
\text { viation }\end{array}$} & \multirow[t]{2}{*}{$\begin{array}{l}\text { Std.E } \\
\text { rror } \\
\text { Mean }\end{array}$} & \multicolumn{2}{|c|}{$\begin{array}{l}95 \% \text { Confidence } \\
\text { Interval of the } \\
\text { Difference }\end{array}$} & & & \\
\hline & & & & Lower & Upper & & & \\
\hline Pair1 & & & & & & & & \\
\hline $\begin{array}{l}\text { Exp. group pre test scores } \\
\text { Exp. group post test scores } \\
\text { Pair2 }\end{array}$ & -16.333 & 16.020 & 2.925 & -22.315 & -10.351 & -5.584 & 29 & .000 \\
\hline $\begin{array}{l}\text { Con. group pre test scores } \\
\text { Con. group post test scores }\end{array}$ & -11.233 & 11.743 & 2.144 & -15.618 & -6.848 & -5.239 & 29 & .000 \\
\hline
\end{tabular}

Based on the results, both groups get better results in the post-test rather than pre-test(table 5.5). It means that the correlation within each group is negative and within both groups, post-test scores are more than pre-test scores.

\section{Discussion}

There is now a unanimous consensus among EFL researchers and educators that the quality and quantity of EFL learners' language learning are determined, to a large extent,with learners' vocabulary knowledge (Decarrico,2001; Hatch \& Brown, 1995; Maley, 1986; Schmitt 2000).However, for many EFL learners, vocabulary learning is a challenging task (Catalan, 2003; Hiebert, 2011; Read, 2000). Based on this premise, vocabulary learning strategies have been suggested as techniques which would facilitate vocabulary learning among L2 learners(Coxhead, 2006; Lessard-Clouston, 2008).

Knowing that EFL learners' performance is deeply influenced by their internal factors (Fahim \& Zaker, 2014; Lightbown \& Spada, 2006) and that using vocabulary learning strategies is closely related to the internal factors and mental processes (Catalan,2003), this study attempted to systematically investigate the association among EFL learners' critical thinking and vocabulary learning.

Vocabulary learning is a multifaceted process which involves many mental processes, i.e. memorizing words, being able to recall them, and using them appropriately (Nation, 2004; Verhallen \& Schoonen,1993). On the other hand, CT is a significant internal factor which is believed to have a major influence on the process of learning and the way EFL learners deal with input and produce output (Chamot, 1995; Nosratinia \& Zaker, 2014).

Assessing the effect of applying critical thinking strategies on vocabulary learning was one of the main objectives of this study. Pressley et al. 1982, Huckin et al. 1993, Gu and Johnson 1996 and Kizlik 2011 found that using critical thinking had a significant effect on students vocabulary learning as one of the learning strategies. 
The findings of this study have some implications for EFL teachers. According to Scharle and Szabo (2000), the class time for vocabulary is so limited when compared with the huge number of vocabulary items needed to be learned. On the other hand, for many EFL learners, vocabulary learning is a challenging task (Catalan, 2003; Hiebert, 2011; Read, 2000). Therefore, along with vocabulary learning strategies instruction, as a direct form for promoting vocabulary learning strategies use, EFL teachers should encourage critical thinking, as one of the important internal factors (Nosratinia \& Zaker, 2014), among their learners.

\section{Conclusion}

Learning vocabulary plays a key role in EFL learning ad teaching. Indeed, the meaning of new words is required to understand in any context. However, it is challenging to teach vocabulary due to the lack of confidence in vocabulary teaching. It is, in fact, difficult for teachers to start their instruction effectively (Berne \& Blachowicz, 2008). It is therefore suggested that L2 vocabulary knowledge is enhanced if the teachers provides different strategies of vocabulary learning including critical thinking strategies. Most of the findings of this study turned out to be quiet congruent with those of Gu and Johnson's (1996), Schmitt's (1997), Kudo's (1999) and Gu's (2003) research.

In this research, students tend to use many strategies such as Note-taking, Guessing Strategies, skillful Use of Dictionary and so on in learning vocabulary .Students did not believe in memorization based on the results. They rather believed that words should be studied and put to use.

Fan (2003) highlights the importance of helping EFL students understand the significance of vocabulary learning strategies and encouraging them to develop effective strategies of their own. EFL teachers are, therefore, suggested to inform EFL learners of the ways through which critical thinking can contribute to learning more independently, reliably, lastingly, and effectively. This is due to the fact that language learners are required to play their role properly in order to facilitate and optimize the complicated process of learning. On the other hand, syllabus designers, as providers of a great portion of the language learning setting should take into consideration learners' individual differences, especially their critical thinking ability which can result in intellectual, active learners.

In conclusion, EFL learners can learn vocabulary effectively through different strategies of vocabulary learning despite its challenge. Learners should then be provided with strategies they lack. To do this, teachers should take into considerations the willingness and readiness of learners' to receive trainings and find the most effective way to introduce the strategies to their students.

\section{Acknowledgements}

Our special thanks to Universiti Sains Malaysia for their support in providing USM Fellowship Scheme for this study. 


\section{References}

Allen, V. F. (1983). Techniques in teaching vocabulary. New York, N.Y., Oxford University Press: Oxford.

Astleitner, H. (2002). Teaching critical thinking online. Journal of Instructional Psychology, 29(2), 53-7.

Berne,J.I., \& Blachowicz, C.L.Z.(2008).What reading teachers say about vocabulary instruction:Voices from the classroom.The Reading Teacher,62(4),314-323. http://dx.doi.org/10.1598/RT.62.4.4

Boloori, L. (2010). The relationship between critical thinking and performance of Iranian EFL learners on the inferential reading comprehension test. Unpublished master's thesis, Azad University of Takestan, Iran.

Brookfield, S. D. (2010). Developing critical thinkers: Challenging adults to explore alternative ways of thinking and acting. The Jossey-Bass higher education series and the Jossey-Bass management series. San Francisco, CA, US: Jossey-Bass. xvi, 293 pp.

Catalan, R. M. J. (2003). Sex differences in L2 vocabulary learning strategies. International Journal of Applied Linguistics, 13(1), 54-77. http://dx.doi.org/10.1111/1473-4192.00037

Chamot, A. (1995). Creating a community of thinkers in the ESL/EFL classroom. TESOL Matters, 5(5), 1-16.

Chamot, A. U. (1999). Learning strategy instruction in the English classroom. Retrieved January 7, 2007 from http:// www.Jalt-publications.org/tlt/article/1999/Chamot/

Connor, K. M., \& Davidson, J. R. T. (2003). Development of a new resilience scale: The Connor-Davidson resilience scale (CD-RISC). Depression and Anxiety, 18, 76-82. http://dx.doi.org/10.1002/da.10113

Cottrell, S. (2005). Critical thinking skills. Developing effective analysis and argument. New York: Palgrave Macmillan.

Coxhead, A. (2006). Essentials of teaching academic vocabulary. Boston: Houghton Mifflin.

Davidson, B. W. (1998). Comments on Dwight Atkinson's "a critical approach to critical thinking in TESOL": a case for critical thinking in the English language classroom. TESOL Quarterly, 32 (1), 119-123. http://dx.doi.org/10.2307/3587906

Decarrico, J. S. (2001). Vocabulary learning and teaching. In M. Celce-Murcia (Ed.), Teaching English as a second or foreign language (3rd ed.; pp. 285-299). Boston: Heinle \& Heinle.

Dornyei, Z. (2005). The psychology of language learner: Individual differences in second language acquisition. Mahwah, NJ: Lawrence Erlbaum Associates.

Duron, R., Limbach, B., \& Waugh, W. (2006). Critical thinking framework for any discipline. International Journal of Teaching and Learning in Higher Education, 17(2), 160-166. 


\section{Macrothink}

Journal of Studies in Education

ISSN 2162-6952

2016, Vol. 6, No. 2

Ehrman, M. E., Leaver, B. L., \& Oxford R.L.(2003).A brief overview of individual differences in second

language learning.System,31,313-330.http://dx.doi.org/10.1016/S0346-251X(03)00045-9

Fahim, M., \& Zaker, A. (2014). EFL learners' creativity and critical thinking: Are they associated? Humanising Language Teaching, 16(3). Retrieved from http://www.hltmag.co.uk/jun14/mart01.ht

Fan, M. Y. (2003). Frequency of use, perceived, usefulness, and actual usefulness of vocabulary strategies: A study of Hong Kong learners. The Modern Language Journal, 87(2), 222-241. http://dx.doi.org/10.1111/1540-4781.00187

Firth, A., \& Wagner, J. (1997). On discourse, communication and (some) fundamental concepts in SLA research .Modern Language Journal, 81(3), 285-300. http://dx.doi.org/10.2307/329302

Gu, Y., \& Johnson, R. K. (1996). Vocabulary learning strategies and language learning outcomes. Language Learning, 643-679. http://dx.doi.org/10.1111/j.1467-1770.1996.tb01355.x

Gu, Y-Q. \& Hu, G-W. (2003). Vocabulary learning strategy, vocabulary size and English achievements. In Wen, Q. [Ed.] Empirical studies on English learning strategies. Xi'an: Shanxi Normal University Press.

Halvorsen, A. (2005). Incorporating critical thinking skills development into ESL/ EFL courses. The Internet TESL Journal, 11(3), 1-5.

Hatch, E., \& Farhady, H. (1981). Research Design and statistics for applied linguistic.Tehran: Rahnama Publications.

Hatch, E., \& Brown, C. (1995). Vocabulary, semantics, and language education. Cambridge: Cambridge University Press.

Hiebert,E. H. (2011). Growing capacity with literary vocabulary: The megaclusters framework. $\quad$ Retrieved from http://americanreadingforum.org/yearbook/11_yearbook/documents/Hiebert\%20KEYNOTE. pdf

Honey, P. (2000). CT questionnaire. Retrieved October 8, 2009, from Peter Honey Learning Website: http:// www.Peter Honey Publications.com

Huckin, T.; Haynes, M. \& Coady, J. (Eds.) (1993). Second Language Reading and Vocabulary Learning.Norwood, NJ: Ablex. http://dx.doi.org/10.1017/S0272263199002028

Huckin, T., \& Coady, J. (1999). Incidental vocabulary acquisition in a second language: A review. Studies in Second Language Acquisition, 21(2), 181-193. http://dx.doi.org/10.1111/j.1540-4781.1993.tb01957.x 
Hulstijn, J. H. (1993). When do foreign-language readers look up the meaning of unfamiliar words? The influence of task and learner variables. The Modern Language Journal, 77,139-147. DOI: 10.1111/j.1540-4781.1993.tb01957.x

Kadir, M. A. A. (2007). Critical thinking: A family resemblance in conceptions. Journal of Education and Human Development, 1(2), 1-11.

Kamali, Z., \& Fahim, M. (2011). The relationship between critical thinking ability of Iranian EFL learners and their resilience level facing unfamiliar vocabulary items in reading. Journal of Language Teaching and Research, 2(1), 104-111. http://dx.doi.org/10.4304/jltr.2.1.104-111

Kizlik, B. (2011). Thinking Skills Vocabulary and Definitions Retrieved January 2, 2011 from http://www.adprima.com/thinkskl.htm.

Knight, S. (1994). Dictionary use while reading: The effects on comprehension and vocabulary acquisition for students of different verbal abilities. The Modern Language Journal, 78(3), 285-299. http://dx.doi.org/10.2307/330108

Kudo, Y. (1999). L2 vocabulary learning strategies. Second Language Teaching \& Curriculum Center, $14 . \quad$ Retrieved from http://www.nflrc.hawaii.edu/networks/NW14/NW14.pdf

Lessard-Clouston, M. (2008). Strategies and success in technical vocabulary learning: Students' approaches in one academic context. Indian Journal of Applied Linguistics, 34(2), 31-63.

Liaw, M. (2007). Content-based Reading and Writing for Critical Thinking Skills in an EFL Context. English Teaching and Learning, 31(2), 45-87.

Lightbown, P., \& Spada, N. (2006). How languages are learned (3rd ed.). Oxford: Oxford University Press.

Mackey, A., \& Gass, M. S. (2005). Second language research: Methodology and design. New Jersey: Lawrence Erlbaum Associates.

Maley, A. (1986). Series editors' preface. In J. Morgan \& M. Rinvolucri (Eds.), Vocabulary. Oxford: Oxford University Press.

Mimbs, C. A. (2005). Teaching from the critical thinking, problem-based curricular approach: strategies, challenges, and recommendations. Journal of Family and Consumer Sciences Education, 23(2), 7-18.

Mirzai, Z. (2008). The relationship between Critical Thinking and Lexical Inferencing of Iranian EFL Learners. Unpublished master's thesis, Azad University of Science and Research, Tehran, Iran

Mok, J. (2010). The new role of English language teachers: developing students' critical thinking in Hong Kong secondary school classrooms. The Asian EFL Journal Quarterly, $12(2), 262-287$. 
Moore, J. 2005. 'Natural language learning (3)'. English Teaching professional 36: 29-31.

Myers, B. E., \& Dyer, J. E. (2006). The influence of student learning style on critical thinking skill. Journal of Agricultural Education, $47 \quad$ (1), 43-52. http://dx.doi.org/10.5032/jae.2006.01043

Nation, P. (2004). Evaluating your vocabulary program. In Y. Leung \& Y. Chen (Eds.), Selected papers from the thirteenth international symposium on English teaching (pp. 91-97). Taipei, Taiwan: The Crane

Noddlings, N. (2006). Critical lessons. What our schools might teach but do not. New York: Cambridge. http://dx.doi.org/10.1017/CBO9780511804625

Norton, B. (2001). Non-participation, imagined communities, and the language classroom. In M. Breen (Ed.), Learner contribution to language learning: New directions in research (pp.159-171). London: Longman.

Nosratinia, M., \& Zaker, A. (2013). Autonomous learning and critical thinking: Inspecting the association among EFL learners. Paper presented at the First National Conference on Teaching English, Literature, and Translation, Shiraz University, Shiraz, Iran. Retrieved from http://www.civilica.com/Paper-TELT01-TELT01_226.html

Nosratinia, M., \& Zaker, A. (2014). Metacognitive attributes and liberated progress: The association among second language learners' critical thinking, creativity, and autonomy. SAGE Open, 4(3), 1-10. http://dx.doi.org/10.1177/2158244014547178

Palmberg, R. 2004a. Developing EFL Learners' Vocabulary Awareness. Karperö: PalmsoftPublications in association with EnglishClub.com. Available from English.Club.com at http://www.englishclub.com/esl-resources/ebdva.htm

Paribakht, T.S., \& Wesche, M.B. (1993) The relationship between reading comprehension and second language development in a comprehension-based ESL program. TESL Canada Journal. 11(1): 9-29. 1993. http://dx.doi.org/10.18806/tesl.v11i1.623

Paribakht, T. S., \& Wesche, M. (1996). Enhancing vocabulary acquisition through reading: a hierarchy of text-related exercise type. The Canadian Modern Language Review, 52, 155-178.

Paul, R., Elder, L., and Bartell, T. (1997). A Brief History of the Idea of Critical Thinking. Retrieved December2010 from http://www.criticalthinking.org/CriticalThinking_org

Paul, R., \& Elder, L. (2005). A guide for educators to critical thinking competency standards. New York: Foundation for Critical Thinking Press.

Pressley, M., Levin, J. R. \& Miller, G. E. (1982). The keyword method compared to alternative vocabulary learning strategies. Contemporary Educational Psychology, 7, 50-60. http://dx.doi.org/10.1016/0361-476X(82)90007-8

Read, J. (2000). Assessing vocabulary. United Kingdom: Cambridge University Press. http://dx.doi.org/10.1017/CBO9780511732942 


\section{Macrothink}

Journal of Studies in Education

ISSN 2162-6952 2016, Vol. 6, No. 2

Reed, J. H. (1998). Effect of a model for critical thinking on student achievement in primary source document analysis and interpretation, argumentative reasoning, critical thinking dispositions, and history content in a community college history course, Unpublished Ph.D. dissertation . College of Education University of South Florida.

Robinson, P. (2002). Individual differences and structured language learning. Amsterdam: John Benjamins. http://dx.doi.org/10.1075/11lt.2

Scharle, A., \& Szabó, A. (2000), Learner Autonomy - A guide to developing learner responsibility .Cambridge university press.

Schmitt, N. (1997). Vocabulary learning strategies. In N. Schmitt \& M. McCarthy (Eds.),Vocabulary description,acquisition and pedagogy (pp.199-228). Cambridge: Cambridge University Press.

Schmitt, N. (2000). Vocabulary in language learning. Cambridge: Cambridge University Press.

Thorburry, S. (2002).How to teach vocabulary.England:Pearson Education Limited.Ur, P., (1998). A course in language teaching.Cabridge University Press.

Ustunuoglu, E. (2004). Language teaching through critical thinking and self-awareness. English Teaching Forum, 42(3), 2-7.

Verhallen, M., \& Schoonen, R. (1993). Vocabulary knowledge of monolingual and bilingual children. Applied linguistics, 14, 344-363.

Waters, A. (2006). Thinking and language learning. ELT Journal, 60(4), 319-327. http://dx.doi.org/10.1093/elt/cc1022

Zimmerman, C. (1997). Historical trends in second language vocabulary acquisition. In J. Coady \& Huckin, second language vocabulary acquisition (pp. 5-19). Cambridge: Cambridge University Press. 